\title{
Government and fertility in transitional and post-transitional societies
}

Geoffrey McNicoll

Population Council

Follow this and additional works at: https://knowledgecommons.popcouncil.org/departments_sbsr-pgy

Part of the Demography, Population, and Ecology Commons, Family, Life Course, and Society Commons, and the International Public Health Commons How does access to this work benefit you? Let us know!

\section{Recommended Citation}

McNicoll, Geoffrey. 1998. "Government and fertility in transitional and post-transitional societies," Policy Research Division Working Paper no. 113. New York: Population Council. Version of record: https://www.jstor.org/stable/3115253 
Government and Fertility in Transitional and Post-Transitional Societies

Geoffrey M cNicoll 


\title{
Government and Fertility in Transitional and Post-Transitional Societies
}

\author{
Geoffrey McNicoll
}

Geoffrey McNicoll is Senior Associate, Policy Research Division, Population Council, New York, and Professor, Research School of Social Sciences, Australian National University.

This is a revised version of a paper presented at the Rockefeller Foundation's Conference on Global Fertility Transition, Bellagio, Italy, May 1998. Comments by Rodolfo Bulatao, Ronald Lee, Noriko Tsuya, and other conference participants are acknowledged. 


\begin{abstract}
Five categories of possible government influence on a nation's fertility are explored: (1) through publicly funded programs that explicitly seek to affect family-size outcomes; (2) through the legal order and system of public administration; (3) through measures that affect economic opportunity, social mobility, and gender relations; (4) through public-sector expenditures and transfer payments keyed to age or family status; and (5) through the state's supplanting of local beliefs and traditions with the symbols of national identity and through the parallel expansion of cultural frames of reference. Aside from the first of these, intentions to influence fertility are either incidental or wholly lacking, although the relationships were plausibly implicated in both the historical and contemporary fertility transitions. Delineating the actual nature and range of government influence can be a source of new insights into how to bring about a socially desired path of fertility in the future, both where present fertility is deemed too high and where it may be too low.
\end{abstract}

This material may not be reproduced in any form without written permission from the author. 
The study of human fertility, informed by a welter of household survey data, is focused on family and individual behavior and on the ("proximate") biological or behavioral components into which reproduction can be analyzed. There is a complementary view of fertility that, in contrast, has been relatively neglected. This is fertility seen as part of the core generic problem of societal management - where the focus is not on micro-level conditions, preferences, and decisions but on the fertility consequences, whether recognized or not, of how a society organizes and governs itself. This alternative perspective is my subject.

In some respects, it is a return to the interests of the classical population theorists. There is much good sense about it in Malthus. Subsequently, explanations of demographic change increasingly left the state in the background. For example, demographic transition theory ties fertility decline to economic and social, not political, development. When admitted, government roles are confined to the programmatic - although they are sometimes then acclaimed. Only in post-transition regimes, with societies facing drastically low fertility, is the state routinely brought back in.

There was some justification for this narrow and selective attention to government. The milestones of the development process were indices of economic and social attainment: income, literacy, health, and the like. Fertility was a natural addition to the list. The indices moved not in lock-step, but in a ragged group (see Chenery and Syrquin 1975). In contrast, political circumstancesform of government, administrative reach, delimitation of the private sphereseemed more variable. Even in the more economically advanced societies, material progress and low fertility apparently could be attained under widely different political regimes. This justification such as it was, however, has been eroding for some time. The dismal experience of "failed" and predatory states in the third world, the spectacular collapse of Communism in the second, and the general retreat from statism in the first, have suggested a closer connection between political structures and economic outcomes than had formerly been accepted. A political connection to demographic outcomes might exist as well. 
Government is not, of course, a simple thing. It is both an endogenous element in the social system and a quasi-exogenous agent of change. Neither aspect captures the whole: government is more than a mere creature of interest groups in the society, but much less than an independent, rational entity engaged in the design and execution of public policy. And government is itself a constellation of interests and capabilities, with vaguely defined and mutually incompatible objectives, its perceptions and procedures influenced by a particular historical experience. Fertility sometimes appears prominently on its radar screen, eliciting alarm and forceful action; more often it is no more than a remote blur. Government response to fertility levels that are seen as too high or too low is typically hesitant, clumsy, and often, no doubt, futile. At the same time, fertility may be strongly influenced inadvertently by government actions taken with no demographic intent.

My aim in this essay is to explore the scope and nature of this influence, deliberate or inadvertent. I start with a sketch of fertility change as a "natural" accompaniment of social and economic development. Government stays in the margin of such an account, at various stages a propagandist on population matters and a manager of family planning programs-shifting, in low-fertility settings, to promoter of vaguely family-friendly legislation and welfare-state institutions. It is portrayed as either distantly (toothlessly) signaling its preferred demographic regime or actively modifying fertility outcomes to accord with a declared social interest - though doing so with full respect for individual preferences. Both portraits are arguably misleading. On the one hand, the range of government actions that impinge on fertility is considerably wider than often appreciated, not least by government itself. And on the other hand, government is almost always prone to overestimate its persuasiveness on the matter, short of recourse to pressure: taking credit for changes originating elsewhere, finding selfjustifying explanations for null results, and quite willing to discard the sover- 
eignty of individual preferences. These considerations are discussed in the next several sections below. I will deal mainly with government influence on fertility over the conventional course of development, but touch also on the post-transition situation of very low fertility. Finally, I consider whether any of the foregoing potentially contributes to the desideratum of an enriched fertility theory-in particular, whether a political perspective can potentially offer a more seamless view of fertility determination, without the sharp disjunction between a theory of transition and a (yet-to-emerge) theory of low fertility.

\section{Fertility Change: A BACKgROUND SKETCH}

Consider the process of fertility transition embedded in a society, economy, and culture, but, for the time being, leaving government aside.

\section{Society and fertility: The classical picture}

The "classical" account of fertility decline refers to the economic and social transformation wrought by industrialization and urbanization. There are new resources and technologies, shifts in the legal and political order, changing values about family and authority, even anticipations based on awareness of change elsewhere. Perhaps most important, there is an opening up of the social and economic "space" around families and individuals-wider cultural horizons and greater opportunities for mobility, both social and geographic. People seek to maintain or improve their relative positions in a society that is now characterized by new status-linked consumption patterns and new requirements for investment in human capital. New labor market opportunities, especially for women, and rising consumption and investment demands, when translated into effects on the utilities and costs of children, prove strongly antinatalist. In effect, people find that the game has changed around them and they have no alternative but to play by the new rules. 
Judith Blake (1972b) has given a cogent depiction of the Western fertility transition in these terms. She was of course writing in a well-cultivated vein of thinking on the subject, dating back to Malthus and virtually a commonplace by the end of the nineteenth century. The fertility link is captured in Arsène Dumont's awkward metaphor of "social capillarity." F. W. Taussig (1911: Ch. 53), in a textbook that was the Samuelson of its day, attributed fertility decline to "awakened ambition of the individual...":

The causes of the declining birth rate are to be found in the intellectual and material forces which have so wonderfully stirred the people of western Europe during the last century: the spread of education, newspapers and books; cheap movement by railway and steamship; the stirring of stagnant populations by the new modes of employment, by large scale production and the factory system, by the changes through emigration.

Marital fertility was dropping "because parents are solicitous not only to maintain, but to raise, the social and economic position of their children." In the United States, "The influence of free institutions and of free opportunities is to lessen, possibly to destroy, the caste-like character of social classes.... [T] he leaven of social and economic ambition slowly but surely affects them. It makes well-nigh certain a relaxation of the rate of growth in population" (ibid.).

There may have been something structurally special about Northwest European families (and East Asian families—see Greenhalgh 1988) that facilitated this mobility-fertility connection. South Asian and African fertility transitions, some have argued, have been impeded by the weakness of the nuclear family as a solidary or budgetary unit. Economic opportunity itself, however, is a powerful incentive for sloughing off extended kin-ties as their social security value lessens. 
In some accounts of fertility transition, development is identified with a progressive relaxation of social control over families and individuals. There may indeed be a perception within the society of increasing freedom in personal and social behavior, associated with decay of the kind of informal neighborhood surveillance that is a feature of community life in traditional settings and with the opening of new routes of social mobility. But the shift is away from a geographic dimension of control, not from the fact of control. Spatial relocation and longdistance communication allow a reassignment of group affiliations and obscure the resulting patterns of behavioral conformity; the patterns are still there. Thus, prosperous low-fertility societies are not characterized by a high variance in completed family size but by a tight clustering of size options. In effect, the family has been reconfigured to mean one or two children-or none-with social pressures realigned accordingly. Family sizes above three become almost deviant. Only in a few outlier subcultures is group support for high child numbers to be found, with that behavior becoming one marker of their peculiarity. A satisfactory theory of fertility transition must encompass the factors behind this reconfiguration.

It is difficult to describe this perspective on social change without appearing to make "society" into a conscious, deliberating entity. That is of course absurd. The social pressures bearing on demographic behavior are enmeshed in inherited institutional forms conveying societal interests (and perhaps, as some would argue, biological interests) in survival and continuity, and are likely to be barely recognized. Moreover, they are not just features of premodern or developing countries, vanishing with prosperity; they are realities of social life. Blake (1972a) was specifically including the post-World War II United States when she wrote:

$[R]$ eproduction and replacement, like other societal functions, require an organized allocation of human and material resources. So- 
cieties have resolved this problem of resource allocation by means of diffused control mechanisms (rather than a government planning board, for example), but the mechanisms are nonetheless quite palpably there. And they involve the individual in an articulated and coercive set of constraints.

Her worry at the time was with the "coercive pronatalism" built into a familistic culture but unrecognized in discussions of population policy. In the last quartercentury, the "palpable mechanisms" that once held fertility well above replacement seem to have corroded, leaving others that validate one-child families and childlessness.

Social groups do have a place in the classical picture: fertility is in some measure determined by and within them. They are the locus of values and sanctions that influence the various constituent behaviors in family formation and may in effect be repositories of particular arrays of knowledge and myth. In some cases they might appropriately be seen as subcultures. I do not mean to exaggerate the extent of conformism here, or to downplay the role of individual agency. Individual decisions are ultimately what matter, and individual interests, particularly economic interests, will nearly always have a significant effect on them. Group norms are themselves constructed and reconstructed from overlays of actual behaviors and their accompanying rationalizations, and in consequence are never as rigid or as current as sometimes painted. Moreover, individuals can to some degree adjust their normative surroundings by shifting or reweighting their membership affiliations. A familiar example is the formal constancy but diminishing effect of certain religious prescriptions on sexual morality, as adherents choose other sources of moral legitimation in that domain. However, the scope for such adjustments is itself a societal characteristic, constricted in authoritarian settings and expanding along with the growth and elaboration of civil society. 


\section{Microeconomics, cognition, and fertility}

The economic account of fertility decline covers much of the same ground but is somewhat starker. The direct costs of children increase as parents recognize the growing importance of human capital in the new dispensation, requiring much greater expenditure per child — and with fewer options to spread the burden over kin. Child care, like other nonmarket, time-intensive activities, is seen to have a rising opportunity cost. At the same time, distant economic returns from children in the form of support in old age look insecure. Families and individuals contemplating their reproductive lives conclude that they can do better with fewer children. Improvements in the knowledge and affordability of effective birth control ease the behavioral change.

The economic modeling literature presents stylized pictures of the process. One-period household models show how fertility decisions (and mortality outcomes) might be expected to change with increases in the value of time, working through changes in wages and labor participation and investment in health and education. This microeconomic picture can be given a time dimension by drawing on parallel work on overlapping-generation growth models, which relate fertility levels to the intergenerational transfers that are needed to meet consumption needs in childhood and old age. (See Willis 1998 for a synthesis of this research.) But such models, powerful as they are conceptually and, to a lesser degree, empirically, do not exhaust the subject of fertility determination. In many cases, indeed, it can be argued that the model, once it has been set out, and providing its assumptions on family structure remain valid, can be "folded up" as a taken-for-granted component of the larger picture (see Ben-Porath 1974). Attention can then turn elsewhere: to the dynamics of change in the social structureas in the classical view outlined earlier-and to the perceptions and valuations of the factors entering individual decisions. 
These perceptions and valuations warrant further mention. Not bothering to specify them or to consider how they might be formed is partly economists' shorthand-taking it as self-evident, for example, that price effects are filtered through a preconceptual and informational penumbra-but partly too it is economists' disciplinary conviction that such complications do not count for much.

Can the cultural or "ideational" environment be an autonomous source of behavioral change? Anyone but a thoroughgoing materialist would concede that fertility determinants are both material and ideal, however contentious are views about the balance and the degree of separability between them. On the side of cultural determination, Ron Lesthaeghe points to the process of secularization and growing individual autonomy in driving the so-called first demographic transition in the West, with external systems of authority and morality losing force. The second transition - the continued drop in the fertility of already prosperous societies to well below replacement levels-is linked to the spread of "post-materialist" values (Inglehart's term), notably the goal of individual self-fulfillment. (See Lesthaeghe 1983, 1995; van de Kaa 1996.) Of course, cultural change has an institutional manifestation: the former "systems of morality" were not ethereal beliefs but actual structures of power-a confluence exemplified by the Inquisition and auto da fé. The process of change can be seen as the slow emergence of the concept of a private domain - an arena of beliefs and behaviors that are allowed to be outside the concern of external authority. By and large, family life came to lie within this domain. As tolerance of diversity expanded in postindustrial times, de facto privacy was accorded to a still-wider range of formerly public individual behavior - though the private domain was nonetheless transparent to market forces, making for convergent fertility outcomes.

This makes an appealing picture of liberal development, but is something of a caricature. What counts as private is always subject to contestation, particularly where it involves sex and reproductive behavior. And beyond explicit inter- 
ventions, behavior in the private sphere is still subject to social and cultural pressures from the surrounding society.

Recognition of cultural influence is not to elevate "ideational factors" and diffusion as a preferred explanation of fertility change. As investigations of technological change make clear, there are always many more ideas around than are ever turned into practical application. What determines the matter is the market for ideas: receptivity to change (where path dependency may enter) and, to some degree, fortuity. An application can always be traced back to an idea; hence the idea must have "diffused." But that is hardly adequate as theory. Inadequacy is the greater in a situation where the ideas at issue are not just about contraceptive methods but about family life, gender systems, social mobility, economic opportunity, and much else.

In the recent fertility literature, economic and ideational factors play oddly symmetric roles in explanation. Proponents of each would deny that social change is in part an autonomous process, seeing it instead either as a reflection of deeperseated economic forces or as the outcome of ideational change generated by the diffusion of new ideas, particularly from a Western or globalized culture. Purists on each side see the other as the opposing contender in the explanatory stakes, with no other horses running. For fertility, the result is two mutually incompatible interpretations of the same reality, both of them tending to be asociological. Empirically, ideationists aver, economic explanation has failed, in that survey-based measures of economic status appear to be weak predictors of individual fertility outcomes. Ideational change, not yet subjected to an analogous (equally dubious) test, for the time being retains its a priori plausibility unpunctured. Tertium non datur.

Each of the various sets of factors in this sketch no doubt contributes something to the explanation of fertility. I am not concerned with deciding how muchefforts to identify additive effects are suspect—let alone with banishing any of them. Rather, this view of the process of fertility change serves as a background against 
which to explore the roles of the state - and serves to remind us that there are underlying forces and processes of change in a society that are often, and perhaps nearly always, more significant for the course of fertility than are the actions of government.

\section{CATEgORIZING StATE INFLUENCES}

Along with its economy, social institutions, and cultural patterns, a society of any size and complexity inherits a polity—a political-administrative structure that is the institutional manifestation of the state. Together, these inherited features define a framework of roles and statuses within which individual behavior is played out. In particular, that framework sustains a demographic regime: the set of routine behaviors surrounding cohabitation, marriage, childbearing, and "health-seeking," and their antecedents or supports in patterns of socialization, organization, and economic activity.

By virtue of its mere existence, therefore, the state cannot not influence fertility. There is no position of "neutrality" from which to measure its positive or negative pressures on reproduction. Discussions of government roles in fertility change, however, are usually concerned with more explicit means of behavioral influence than through diffuse social structural or cultural aspects of the polity. They are concerned with cases in which governments deliberately set out to change fertility, or in which they pursue economic and social policies that have fertility change as a desired byproduct — one that provides part of the rationale for undertaking them. Of course, intentions do not necessarily yield intended results, and it is the determinants of outcomes rather than of intentions that are of interest here. Unfortunately, the efficacy of policy measures, pro- or anti-natalist, is itself contentious.

In classifying potential routes of governmental influence on fertility, a two-way scheme-direct versus indirect, or explicit versus implicit-is clearly inadequate. Intentions may matter, or they may not: that issue should not be decided a priori. A better classification would be based on substantive considerations: the hypothesized route of influence and the conceptualization of the pro- 
cess of social change presumed to be operating. On those grounds I would propose the following as the most important ways in which the state impinges on fertility behavior and outcomes:

- The state develops, funds, and manages programs that seek to influence family-size outcomes through information, advocacy, economic inducement, or political pressure.

- The state maintains an overall regulatory regime and system of public administration, providing a legal-administrative setting for civil society, economic activity, and family life.

- The state has a part in determining access and opportunity in the societysocial mobility, returns to effort, distributional equity_particularly through the social stratification and gender systems, thereby affecting the fertility calculus of individuals and families.

- The state designs and undertakes public-sector expenditures and transfer payments keyed to age or family status, thereby affecting the private economics of fertility.

- The state wields the symbols of national identity and cultural continuity that take the place of local beliefs and traditions, setting individual expectations and behavior in a wider national and even global cultural framework.

I discuss these five suggested roles or sets of influences seriatim in the following sections.

\section{THE STATE AND FERTILITY REgULATION}

Social regulation of fertility (or its near-equivalent, of surviving children) is no doubt as old as society, and interference in the matter by government merely formalizes that interest. The perennial government objective has been to boost 
population numbers, with fertility seen as a perhaps more secure source of recruitment than immigration and conquest. Sporadic efforts to design pronatalist rewards and sanctions have been made by authoritarian rulers at least since Augustus - the implication being that left to themselves many fewer women would choose a life of untrammeled childrearing.

Government antinatalist efforts by comparison are recent. They required a credible prospect of Malthusian scarcity or, in its later form, appreciation of a serious demographic drag on development. Deferred by the industrial revolution, this took firm shape only with the sharp acceleration in population growth set off by the twentieth-century mortality declines. Actual government programs to limit that growth by propagation of birth control date only from the 1950s. As experience was gained and some experimentation undertaken (Taichung, Mysore, etc.), initial caution was replaced by enthusiasm and energy.

From the start, birth control programs had another antecedent in addition to Malthusian worries. This was the campaign for women's rights, autonomy, and reproductive health, begun in Western countries in the nineteenth century. From that tradition came much of the ideology that imbued the family planning movement, in particular its strong voluntaristic ethos and the cross-national similarities in its rhetoric and design.

These antecedents did not have to be found in the country setting up the program: in the early years programs were often imposed on a passive and bemused officialdom and populace by enthusiastic foreign donors when the government itself was neither persuaded of the demographic need nor in favor of the program's implicit ideology (see Warwick 1982). In other cases, the voluntarism entailed in the program's actual implementation was less than claimed-in some instances, much less (see McNicoll 1997). But such cases might well have been more numerous had there not been these strong international linkages: had each country designed a program that accorded with its own perception of the urgency 
of the problem and the population groups to be targeted, and managed it in the manner of its own political and administrative practices in other domains. The administrative muscle employed in China, India, and Indonesia in the 1970s supports this proposition.

From the standpoint of fertility theory rather than of population policy, the programs have three potential routes of fertility influence. The first, proclaimed loudest, is through meeting existing "needs" (read demand at zero cost) for modern contraception, in essence by lowering information costs and the supply price. The second route is through shifting preferences, mainly about contraception and the family, in ways that make birth control more acceptable and promote desires for low fertility. This, an ideational change among individuals and couples, is thought to be achieved by presidential speeches, media themes and messages, and contact with extension agents, working through diffusion processes and bandwagon effects. The third route is through political and administrative pressure, sometimes backed by economic sanction, either to gain program "acceptors" or directly to achieve a particular demographic outcome-a one- or two-child family, say.

China's birth control program, as it has evolved in the 1980s and 1990s following the Dengist reforms that reestablished a privatized agrarian economy, exemplifies the second and third routes. It apparently has largely succeeded in persuading people that fertility has significant social as well as private consequences and thus is a legitimate matter for state intervention. It prescribes limits on child numbers and levies fines for noncompliance. The pressure has varied over time and across regions and has been partly vitiated by increasing geographic mobility and other changes that defeat the meticulous monitoring of reproduction that the system requires. Increasing economic differentiation among families erodes the egalitarianism of the policy goal. However, the system in practice is far from rigid: for instance, the quite substantial specified fines, say for a third 
or fourth birth, may in practice be bargained down, given that the village cadres who must collect them are members of the community—see Zhang (1998). Vietnam's program reportedly has some similar characteristics (Goodkind 1995). Fully voluntary birth control programs restrict themselves mainly to the first route, with cautious forays into the second. What have they achieved? After decades of research, that remains a contested matter with sharply disparate readings of the evidence (Pritchett 1994; Potts 1997). To reach an answer requires addressing the counterfactual of what would have happened in a program's absence: presumably not complete passivity in the face of an onslaught of births (the assumption behind some calculations of program effect), but each society pursuing its perceived collective interest in lower fertility within its own cultural framework. Against that standard, the decision to channel birth control energies and resources into those programs is debatable. Indeed, in some readings of the nature of the high-fertility problem, the number of births averted by the programs might even be negative, by preempting moves that relied more on home-grown responses. Multivariate analysis has not settled the question: the identification of "program effort" as an independent factor in fertility decline is itself disputed. "Effort," in the alternative reading, is in part elicited by an increasing demand for birth control (Demeny 1979; Schultz 1994) and thus is not properly identified as a "supply" variable.

Lant Pritchett (1994: 24) calculates that at low per capita incomes the present discounted cost of a child is 100 times larger than the cost of avoiding a child through birth control. The same multiple was once used (by Stephen Enke, and later by President Johnson) as a compelling argument for investing in family planning programs - offering a remarkably cheap way of improving economic conditions. But that supposes that parents are ignorant about contraception or helpless to act in the matter without government support, a quaint notion from a more innocent age. ("Coitus interruptus' has so far not been approved by the Planning Commission or the Government," wrote Gyan Chand, former chief 
economist in India's cabinet secretariat, in 1954, "but the Census Commissioner has referred to it in his Report and with approval" [Chand 1954: 103].) For Pritchett, the implication of the multiple is rather that manipulating birth control costs through family planning programs is unlikely to count for much in childbearing decisions.

Explicit government antinatalist measures extend beyond birth control programs. They include limitations on marriage: once, in many societies, requiring permission from local authorities based on a couple's economic circumstances, now merely specification of a minimum age. (It is often overlooked that such limitations are an accepted exercise of state authority; family planning voluntarism starts later.) Fertility effects are commonly claimed as a partial justification for expanding maternal and child health programs and programs seeking to improve the position of women. Belief in these joint efforts is a prominent assumption of the so-called Cairo agenda, which promotes women's rights and reproductive health mainly on their own merits but with a supposed demographic payoff as well.

Pro-natalist programs under modern conditions of low fertility rely mainly on tax and other material incentives. Apparent effects are sometimes detectable, more often in the tempo of fertility than in lifetime births, but overall the impact of such measures has been fairly marginal (see Demeny 1986b, 1997; McIntosh 1986). Of course, material incentives that are sufficiently large in proportion to family income could certainly be effective, but the budgetary cost entailed would be politically prohibitive. Average parental expenditures on raising a child in the United States today is substantially above $\$ 100,000$ (see Espenshade 1984). A proportionality argument parallel to Pritchett's on birth control can be made about interventions to raise fertility in low-fertility societies: against the actual costs of children, the kinds of monetary incentive offered to parents in most pronatalist programs are trivial.

If the political feasibility constraint is relaxed, a case can be made for a much higher subsidy of parenting. Ronald Lee and Timothy Miller (1997), in 
research undertaken for a study of US immigration, find that the net present value of the "fiscal impact" of an average American birth (that is, the discounted sum of the year-by-year local and federal taxes paid by that person and his/her descendants, less the year-by-year government expenditures imputed to that person) is on the order of $\$ 200,000$ in 1994 dollars - at a 3 percent discount rate. (At 2 percent, the value is roughly doubled; at 4 percent, halved.) Accepting such a calculation, and the assumptions it requires (not only on the discount rate but on productivity growth, congestion costs, and environmental impact), massive government birth subsidies could be justified. The sensitivity of the result to those assumptions, however, is a reason for caution in using the procedure as a means for valuing alternative demographic futures. Of course, societies do not expect to have to collectively purchase their descendants, and in contemplating any actual subsidy program the problem of selectivity — of who is bearing and raising the "purchased" children, and hence, to some extent, what is their "quality"-is a critical but highly sensitive question.

If children cannot be bought at affordable cost, what alternative approaches to sustaining fertility can be found? In authoritarian regimes pronatalism may have a forceful edge - the 1966 Romanian prohibition of abortion, virtually doubling the birth rate for the next two years, is often pointed to; Iranian policies in the early 1980s were in some respects parallel. But it is hard to coerce additional births. Promotional campaigns and symbolic rewards call to mind Stalin's "hero mothers" and are unlikely to influence a cynical populace. Kingsley Davis (1937), seeing no way to maintain population replacement under the usual family pattern of modern societies, foresaw a need for the professionalization of parenthood. Various proposals have been made for how to do so, most of them far-fetched or overtly dystopian (often appropriately cast as fiction). Taussig (1911) scornfully decried the "phalansteries and barracks" he associated with the birth planning of full-blown socialism, drawn in that case from Charles Fourier's heated imagination-though something of the sort was actually to be attempted, albeit briefly, in Maoist China. 
Overall, this experience offers scant encouragement for a government role in fertility management at low-fertility levels. Andrew Cherlin (1988: 24) writes, of the United States, that "fundamental family trends such as changes in divorce, marriage, and birthrates are little affected by government social or economic policies... [A]ny feasible child care program or family allowance in the United States would be unlikely to influence the birthrate very much in either direction.” Frank Furstenberg (1995: 253) concurs: “our ability to engineer family behaviour is limited at best."

Programs concerned with fertility do not of course have to be about simple numbers of births. The potential social interest in demographic outcomes extends to other characteristics of children. It also involves ethical judgments about appropriate aims and means of birth control. Thus governments might seek to override parental desires for sons over daughters that can be exercised through prenatal sex determination and selective abortion, for moral reasons or so as not to be faced with seriously unbalanced sex ratios in the next generation. More generally, governments set ground rules for abortion, which increasingly must take account of ascertainable knowledge of the genetic makeup of the fetus. Notwithstanding the past excesses of eugenics, it is hard to argue that the manifest public interest in "child quality" should deal only with environment and never with heredity. (Eugenics is the central concern of China's 1995 Law on Maternal and Infant Health Care, which has drawn much less attention than China's onechild policy.) Governments will inevitably be drawn again into this issue as technologies develop that enable parents to interpose their own eugenic wishes at an ever-finer-grained degree of genetic detail.

\section{THE LEgAL AND ADMINISTRATIVE REGIME AND FERTILITY}

The minimalist requirement of government extends little beyond the maintenance of social order. That entails defense against external threat and preserva- 
tion of stability and predictability in economic relationships - at the least, security of property, a system of adjudication, and a capacity to enforce contracts. This was a theme of the classical economists, and is echoed by modern libertarians. Minimalism in a sense also exists when there is thoroughgoing administrative incapacity, as in the case of the so-called failed state. Most actual governments, of course, are far from minimalist. At the interventionist extreme, they may attempt to minutely regulate social and economic life through surveillance and sanction. In modern social democracies, a more benign but still meticulous regulatory regime has acquired the sobriquet of the nanny state. Countries are arrayed across this spectrum, and over time have relocated themselves.

Cutting across the libertarian-nanny state axis is what might be termed the administrative-legal dimension. Early in the development process-perhaps well before it - national governments discover the need for an effective administrative order. Usurping familial and community authority, they strengthen local officialdom, often coopting traditional or elected village leaders as public servants. Sometimes, for a firmer backbone, they introduce a second, parallel hierarchy of military command or state-party cadres. Governance is by fiat. Over time, as described earlier, the processes of social and geographic mobility, accelerated by economic growth, undermine the spatially defined hierarchy of local and regional public administration, replacing it with a national legal order.

We can describe the position or path of change of a given society in terms of these two axes: one measuring the scope and intensity of state intervention, the other, the balance between administrative and legal authority. A typical trajectory for a developing country over the last half-century might see an early espousal of state intervention, followed by a partial retreat, and at the same time a steady shift from fiat to codified civil law. The position at a given time has significant implications for fertility behavior and for the nature and efficacy of fertility policy 
(see McNicoll 1997 for a fuller discussion). As a simple illustration, consider the four situations generated by low and high combinations of values along each axis.

- Minimalist state/rule by fiat. Distancing of the state from local affairs here is more likely to reflect administrative incapacity than libertarian principle. Governments try to impose authoritarian control but their efforts are erratic and often predatory and economically damaging. Regional underadministration leaves a power vacuum that is filled by tax-farmers or mafiatype entities (see Putnam 1993). In extreme cases there may be a more radical institutional decay and breakdown of social order (see R. Kaplan 1996). Fertility outcomes under these conditions bear little or no relation to societal interests. For families in such settings efforts to create and maintain informal security alliances take precedence over any long-run economic-demographic calculations. Fertility policy measures are irrelevant.

- Intrusive state/rule by fiat. An authoritarian state with effective administrative outreach through an Interior Ministry or equivalent can apply that apparatus in support of line-ministry activities deemed of particular significancefor, say, national security or development. Dealing with high fertility has sometimes been seen as such an activity, accorded quasi-security status. It was arguably so in 1970s' China, with antinatalist measures supported by a mobilized Communist Party apparatus; in Indonesia in the same decade, with support from a militarized local government system (and sporadically from the military itself); and in Emergency-era India, with general backing from the civil service and local government. In other circumstances, authoritarian states have sought to raise fertility. There is no doubt that fertility can be influenced to some degree by close-range administrative pressures: neighborhood-level social pressures once did as much. However, passive non- 
compliance—one of the "weapons of the weak" (Scott 1985)—may be an effective counterforce, overcome only at high political cost. We can note also that locally based authority tends to erode over the course of development and this route then ceases to be available.

- Intrusive state/rule of law. This combination would typically be associated with modern welfare states, where social and economic development is likely to have already brought about low fertility. Elaborate social policy objectives are pursued through family law, personnel-policy requirements imposed on employers, and tax expenditures. Very low fertility may be flagged as a problem but raising fertility has rarely assumed a prominent place in the social policy agenda of welfare states beyond measures promoting a benign family-friendliness. (I return to this topic below.) This administrative combination is not only associated with social democracy. Although conservatism broadly seeks the dominance of society over the state, social conservatives are willing to have the state's legislative backing for their particular moral agenda — one that embraces familism. In low-fertility situations, they would likely push for pronatalist outcomes through fiscal or ideational means, but would also permit pro-family policies to be embodied in law and public administration.

- Minimalist state/rule of law. The administrative patterns that best promote economic development are usually held to be those that expand economic freedom within a framework of secure property rights. (The recipe is sufficient rather than necessary: rapid economic growth can be attained in the absence of political freedom and even - as in China-with curtailed demographic freedom.) Economic success brings fertility transition as a virtually certain byproduct. For economic conservatives, consequent low fertility would 
not be any cause for intervention; rather, it would be accepted as the result of the free choice of individuals.

The last two of these combinations describe issues of law and public administration that are important in fertility determination in low-fertility situations. Welfare state institutions and the intergenerational transfers they accommodate require strong administrative support, not least to maintain the revenue side of the state budget. The globalization pressures that have pushed the partial dismantlement of those institutions by disadvantaging countries with very high governmental shares of GDP have restrained the redistributionist inclinations of the state. Child allowances are among the transfers that have been squeezed (see the later discussion of public transfers). Of course, a government may be philosophically disinclined to privilege families and their reproductive role, preferring to deal solely with individuals: that stance has a hard-nosed consistency to it, but would be a curious relinquishment of policy interest in the society's future. A similar indifference to fertility levels might be found during a period in which major international institutional changes are underway-for example, as currently in the development of the European Union, with emergence of a supranational labor market and centralization of some areas of social policymaking. Eventu-

ally, however, the prospect of a substantial, continued population decline is likely to elicit a strong political response, necessarily with significant administrative implications.

\section{The State, Social Mobility, AND FERTILITy}

When state and society are used as contrasting terms, society refers to those social groups and affiliations that are not part of or beholden to the state and its agencies. The contrast is not one of potential authoritarianism versus benign civility: behavioral control may be stringent or lax on either side. As Joel Migdal 
(1988) and subsequently many others have noted, strong states often go with weak societies, and vice versa. And as not a few examples of political and social disorder and economic retrogression remind us, state and society can be simultaneously weak.

I noted earlier the strong emphasis that theorists of fertility decline put on opportunity, especially for economic and social mobility. The argument is that much of the fertility-reducing effect of economic development results from the breakdown of rigid stratification and gender systems as new technologies and institutions open new routes of upward mobility - and pose new threats to those disinclined to respond. These systems can also be transformed or disrupted by political change: indeed that is a major source of challenge to their rigidity. Blake (1972b) saw eighteenth-century France as a notable case in point, with the early onset of fertility decline a consequence of the political forces shaking up a traditional, ascriptive stratification system. This began well before the technological advances of the agricultural and industrial revolutions.

Major land reforms are an evident source of change in stratification systems. The clearest examples are the post-World War II reforms in Taiwan and South Korea, in which landlords were bought out by the government (although their gains were soon inflated away), leaving a new class of owner-smallholders in some respects resembling European peasant proprietors-with the same inclinations toward low fertility. China is a more drawn-out and much bloodier version of the same story. The violent suppression of China's landlord class in the early 1950s was followed by an economically damaging series of collectivizations, culminating in the disastrous communes. Fertility decline was thereby deferred and eventually had to be jump-started (in the 1970s) by coercive programmatic and administrative measures. Convergence to the Taiwan-Korea agrarian pattern in economy and demography finally came with the Dengist reprivatization of 1978-albeit leaving land still formally in collective ownership-releas- 
ing the energies and innovativeness of peasant proprietorship. (See Greenhalgh 1990 for an incisive analysis of this experience.)

Gender systems, sustained through early acculturation and socialization within the family unit, are less easily disrupted in the short term. They even tend to be resistant to the radical reforms nominally imposed by revolutionary regimes - as the position of women in communist China attests. Over the longer term, of course, many forces make for lessening gender inequality in the formal economy-with its accompaniment, an increasing problem of maintaining replacement-level fertility (see below).

Are there more-routine kinds of state action that affect opportunity and mobility? State organization and funding of education is an evident candidate here, as least at the secondary and tertiary levels. The distributional effect may be lessened by the fact that the beneficiaries typically are disproportionately drawn from the higher socioeconomic classes. For behavioral change, however, it is likely that what matters more than the odds of admission to, say, secondary schooling is the competition that is generated for access to a potential path to greater autonomy or upward mobility. Even if the odds are weighted against successful achievement, the prospect of access may still be a strong motivation for restricting fertility. Drastically low odds, of course, will preclude change: the system, its public funding notwithstanding, will then preserve the status quo, socioeconomic and demographic.

Intergenerational mobility may be affected by fertility differentials even in generally prosperous, low-fertility societies. Higher-fertility families are more likely to be poor, meaning that children are disproportionately raised in poverty, benefiting less both from socialization within the family and from the formal educational system. (See Blake 1985; Sowell 1983.) Government interventions to promote equality of educational access, like the long running Head Start program in the United States, are primarily aimed at overcoming poverty-based disadvantage; some part of that disadvantage is fertility-related. 


\section{The State, Public Transfers, And Fertility}

As an oppositional pair, state versus market is perhaps even more familiar than state versus society. Both pairs imply arguments for curtailment of state power. In one case, the state is assumed to have some innate expansionary tendencies that impede the development of civil society. In the other case, the state is seen as damaging economic development either by intruding into fields beyond its competence or by engaging in rent-seeking activities. But whereas civil society, as we saw, is not a requirement for vigorous economic performance or for progress in demographic transition, at least until late in the day, the narrower economic liberty of the free market is now increasingly seen as a requirement. The debate on state versus market has been decisively won by the market. The often-derided dictum of the 1974 Bucharest population conference, that "development is the best contraceptive," left open the option of a heavy state role. The paraphrased stance of the US delegation to the Mexico City conference a decade later was that "capitalism is the best contraceptive." Even more excoriated at the time, this view has gradually found much wider acceptance.

The presumption underlying it is that the market economy is best able to foster rapid economic growth and that the same ingredients, such as achievement-orientation and the shaking up of tradition, will initiate or hasten fertility decline. This is less a facilitating role for the state in the fertility transition than abnegation of a potentially impeding role - though recognizing, as discussed above, that an effective market economy calls for skilled, if minimalist, governance. Contrary instances, where the state's role has been economically disastrous, are of course quite common-where the government has snuffed out economic progress and with it any near-term prospect for social development. E.L. Jones (1988) presents a whole array of such cases, spread over several centuries of world history. Africa offers some more-recent instances. Rent-seeking proves an irresistible temptation to ruling elites, leading to predatory or extortionate 
policies that ultimately kill the economic goose. Economic collapse is accompanied by social disorder - or potential disorder that elicits harsh repression. Both development and demographic transition are pushed back to square one.

The state may also have a more direct economic influence on fertility through what it does within its share of the economy. It manages the public component of physical and social infrastructure. It directs public expenditures toward (or away from) programs benefiting young parents. And, to a substantial and increasing degree, it makes transfer payments among population groups. Such expenditures and transfers-more strictly, expectations about them-may significantly modify the economics of fertility as seen by parents or prospective parents. (See Lee 1994; Willis 1994, 1998.)

To amplify this we need to backtrack a little. The fact of childhood- and old age-dependency over the human lifecourse necessitates an institutional means of managing inter-age transfers. The family is in part a device to meet these consumption needs. In isolated groups like hunter-gatherers, a Darwinian argument would predict that there would be net positive transfers from parents to children—which empirical evidence seemingly bears out (H. Kaplan 1994). In agrarian societies, the evidence is more mixed, but under certain patriarchal regimes there appears to be a net benefit to elderly survivors from having a larger family (the premise of the "Caldwell hypothesis" on fertility transition). Whatever the biological factors involved, fertility decisions at the margin are potentially affected. The state intrudes into this domain when it defines a public interest in health and education and, perhaps later, in the welfare of the elderly, and when it specifies how families and children are to be treated in the tax code. Public expenditures in these areas may add to or substitute for private expenditures, in either case altering the (private) fertility calculus. Typically, it is argued, by socializing some part of childrearing costs while leaving old-age support to the family, the state in effect promotes high fertility. In aging, mature economies, 
the position may be reversed: private childrearing costs now are high, reflecting the need for heavy, partly private educational investments and the magnitude of parental opportunity costs, while old-age dependency costs are substantially socialized through pay-as-you-go pension schemes. Net public-sector transfers hence go decisively toward the old, discouraging childbearing-_"reproductive shirking," Robert Willis (1994: 148) calls it.

Transfers in a society become institutionalized as entitlements and are politically costly to change. In effect they become expectations against which economic decisions are taken. Removal of popular subsidies or introduction of user fees for public services, often demanded of countries in economic difficulties as part of structural adjustment programs, are familiar causes of civil disorder. In the same way, fertility-related transfers-likely to be unrecognized as such-acquire entrenched support and become givens in a society, like the builtin pronatalism that Judith Blake pointed to (see above) or the bias against young families and in favor of the elderly that Samuel Preston (1984) documents. In a study of Egypt's fertility, Philippe Fargues (1997) notes that the onset of the steep fertility decline after 1985 coincided not with any development in population policy or program but with measures of economic liberalization that curtailed state subsidies to consumption and necessitated sharply increased family expenditures on health and education.

Recent decades have seen a substantial and virtually worldwide shift from state to market in many areas of life, a process that still continues. Daniel Yergin and Joseph Stanislaw (1998), after describing this shift, discuss the circumstances under which it might halt or be reversed. They identify five "tests" that will shape people's views of the market economy and "provide signposts to the future frontier between state and market" (p. 382). They are: (1) does the market deliver sufficient jobs, consumer goods, and environmental amenity? (2) does it provide requisite "fairness" of opportunity and rein in greed? (3) does it leave scope for 
cultural variation and maintenance of national identities? (4) can it cope with an increasing role in environmental protection? and (5) can it cope with emerging demographic patterns, notably population aging? For population aging, we can read low fertility. Aging will create enormous pressures to raise taxes to finance transfers to the elderly, raising the government's share of the economy and possibly (by squeezing wage earners) further depressing fertility. Indeed, there may still be such a fertility effect under the likely move toward sheltering those transfers within a vested or even largely privatized social security system.

\section{The State, IDEATional Change, AND Fertility}

The cultural counterpart of the centralization of authority in the early part of political development is the ideological creation of the nation-state. Regional cultural distinctiveness does of course remain-especially when associated with ethnicity-but the state endeavors to monopolize the symbols of nationhood. Nationbuilding, especially when arrived at late, can be a fairly deliberate and self-conscious process, entailing selective borrowing from history to support a legitimating and heroic past and creation of the necessary accoutrements for international distinctiveness (flag, anthem, ceremony, and the like). Even in longestablished polities, supposedly time-honored customs and practices often turn out to be of relatively recent design, as studies of the "invention of tradition" have demonstrated.

The state thus constructed wields these various symbols to create a potent source of identity that overlays and may eventually all but extinguish local and kin-based loyalties. The process is what Clifford Geertz (1963) termed the "integrative revolution." The classic discussion of it is by Benedict Anderson (1991). Those earlier affiliative ties were the routes of social pressure on fertility, serving to maintain elaborate family systems, to reinforce gender roles, to redistribute childrearing costs, and to blur the economic autonomy of households. The 
corresponding loyalties evoked by the nation-state may be strong but are amorphous, as are the pressures they accommodate. "Development" typically assumes the status of an ideological goal, justifying the state's imposition of sacrifice in the interest of longer-term gain, and perhaps explaining its award of monopolies or the absence of such appeals to private interest as elections. National security becomes a parallel goal, with its own ideological counterpart to the raft of policies and practices it purports to justify.

Two exceptions to this developmental pattern should be noted. In one the state enforces a neotraditional religious morality and consciously excludes many of the trappings of modernity. However, this is comparatively rare and plausibly a state cannot long preserve that exclusion. In another, more common exception, integration stalls, with ethnic or cultural groupings inventing their own claims to nationhood, often with acute awareness of demographic relativities within the state's boundaries.

The relevance for demographic behavior comes from the shift in cultural frame of reference from the local to the national level, a cognitive counterpart to the expanded options for geographic and social mobility. The change is not the emergence of a "calculus of conscious choice," defining escape from some prerational stage of existence (a farfetched notion), but a rearrangement of the considerations that enter fertility decisions. The nation-state is not of course the end point in this process. Cultural autonomy and distinctiveness at the national level are continually eroded by international influences as part of the phenomenon of globalization, only partly offset by nationalist and nativist cultural regeneration.

Against these major forces, deliberate government efforts to engineer ideational change seem fairly trivial. "Political will" is popularly taken to be a significant factor in the success or failure of birth control programs, especially as manifested in the speeches of political leaders. No doubt the head of state or other authoritative figure can do much to energize program implementation and, for policies entailing service delivery, perhaps improve quality of service. That 
sort of gain, after all, is a routine mark of skilled management. But how much parallel scope is there to inspire change in reproductive behavior itself-even, at a minimally ambitious level, to motivate people to become program clients? In China, Maoist campaigns to encourage emulation of individuals who supposedly displayed exemplary obedience to state and Party dictates soon gave way to the familiar economic incentives of Dengist realism. But perhaps China's authoritarianism makes it a poor example. Bangladesh might be taken as an alternative case. It is sometimes held up as showing fertility decline without development: a kind of "look, no hands!" achievement, the outcome, in some accounts, of pure ideation (or ideation-cum-family planning). More prosaic factors, however, are likely to have been implicated: principally, the marketization of exchange, involving the shift from social capital toward physical and human capital, with their very different rules of investment. The erosion of networks of social support and social control is invisible in economic indices, but may amount to a radical transformation of the economic environment, requiring families and individuals to consider new strategies of economic and demographic life. Those changes, though not directly fostered by the state, indirectly owe much to the government's economic management and public administration.

Modern communications potentially raise new possibilities for state ideational influence. Free-to-air television can serve as a route by which a government's perception of the social interest—say, in family planning—can reach its citizens, through soap operas and similar items of popular culture. With the further spread of communications technology, that influence is diluted. Demographically, however, the messages of the globalized media-on consumerist values, images of the family, attitudes toward individual achievement and gender roles, and views of sexual morality—may be even more powerfully antinatalist.

In advanced market economies, governments would mostly shy away from accepting any explicit state role in ideational change. Their proclaimed task is to reflect rather than lead the views of their electorates, especially on matters 
deemed politically sensitive. Family policy is certainly such an area. At some point, however, low fertility, whether through its population aging effect or through the prospect of a radical diminution in numbers, will demand a state-level response. For the family, the ideal of lineage continuity may have all but vanished, but at the national level, despite talk of the "end of the nation-state," the belief in continuity remains. (The usual "ending" arguments have the nation-state being slowly superseded by supranational instruments and institutions on the one hand and subnational or cross-border entities on the other. For a skeptical and countervailing view, see Canovan 1996.) While population numbers can be sustained by immigration probably for generations to come, very high immigration rates would be called for. Even in pluralistic societies, the demographic turnover implied by this course would itself pose a challenge to national identity. Perhaps the concept of national identity will become fluid enough to tolerate the requisite pace of change under high immigration (McNeill 1984 sketches such a future).

Or perhaps the threat to identity will help to regenerate familistic beliefs and lead to a resurgence of fertility. Or perhaps as-yet-unforeseen changes in the global political or natural environment will make our current expectations about the "problem" of low fertility seem insignificant or ridiculous. But probably more likely is that, accepting that ideational change lies largely outside its capacity to influence, the state will concern itself with what it plausibly can do to affect its fertility, through efforts to redesign social institutions.

\section{GOVERNMENT AS DESIGNER}

In this mapping of state influences on fertility, specific anti- or pro-natalist measures made up only one category. The others had to do with the nature of the government's presence and activities, where intentional fertility effects were incidental-merely reflecting the presumption that development will promote a fertility decline. Replacement fertility was reached in the West without any ex- 
plicit state intervention - indeed, in the face of government opposition-and there is no reason to suppose that the same forces are not operating to bring about fertility declines elsewhere in the world. The novel factor of the last half-century, of course, is the government's role in the spread of modern contraception. Although this role is a frequent cause for self-congratulation, assessments of its effect are exaggerated, perhaps greatly, by use of an inappropriate standard of comparison: government versus nothing. Explicit government efforts to raise birth rates in low-fertility situations have been conspicuously ineffective.

In other spheres, governments are quite ambitious about engineering change. They seek to design whole future urban environments, patterns of industrial organization, and social institutions. The routine expectation that such things are the appropriate bailiwick of government disguises the radical nature of what is being attempted - though the outcome may actually fall far short of the intent. What is the analogue in the population arena? Can the insights derived from the experience of fertility change thus far suggest the kind of institutional innovations that will help to bring about a socially desired path of fertility in the future?

Few would question the legitimacy of a state interest in the matter, at least where demographic trends are far from the socially optimal. Simone Veil (1978: 315), for instance, declares it in straightforward terms: "Avoiding a longterm weakening of a country brought about by a dangerously low birth rate and, inversely, avoiding excessive population growth when it becomes an obstacle to economic development and to the well-being of the population must certainly be among the basic goals of all governments." But if we are to take seriously such a role for the state, it is likely that we must look at more profound kinds of intervention than the programmatic.

In the case of the remaining high-fertility countries, establishment of a secure social order (“just laws impartially administered") and conditions for economic growth (people's "industrious exertions... allowed to have free scope") 
may well be a sufficient design for fertility reduction, with some family planning programmatic backup to give added confidence in the outcome-and to take the credit for it. (The quotes are from Malthus 1820: Ch. 4.) More precise ingredients must come from case-specific institutional analysis-all too rare in a field that celebrates the uniformity of its research protocols. It is not an easy task, but it is notable that the recipe is virtually the same as for promoting broad-based economic development. The required changes do not necessarily yield substantial gains in income in the early years-hence it is possible to observe fertility declining without very much apparent economic growth, as in the case of Bangladesh mentioned above. While administrative pressures can be deployed to lower fertility in the absence of development, the social cost is high and there is some risk of impeding future development.

Turn now to the developed countries. Although their demographic transitions were earlier completed under a wide range of economic and political regimes, these countries have eventually converged to market economies and democratic polities. In those circumstances the market works perhaps too well in undermining societal (and biosocial?) pronatalist pressures and traditions, legitimating in their place a starker economic calculation. Families, and increasingly individuals, must weigh the rich nonmonetary returns from parenthood against the high and ever-rising opportunity costs of children in leisure time and income. The balance, on average, seems to lie below, perhaps much below, a two-child fertility level. The state can attempt to alter that balance through the familiar variety of direct and indirect subsidies of child costs, but these measures, as we noted, are expensive. Moreover, to be significant across the income distribution they have to be quite regressive: richer parents expect to raise more-costly children. Budgetary or tax expenditures to finance the levels of subsidy needed for effectiveness are likely to prove unaffordable (large windfall gains-subsidies needlessly granted to families who would anyway have chosen to have above- 
average numbers of children - are inescapable) or politically unfeasible, given the international competitive pressures on countries to align tax regimes and lower the government share of the national economy.

Given the usual family division of labor, and the usual custodial arrangements under single parenthood, women incur the major time costs of childrearing. They experience more directly the role conflict between parenting and labor force participation. Gøsta Esping-Andersen (1996: 26) sees the problem of "how to harmonize women's employment with family formation" as "one of the greatest challenges for the future welfare state." Jean-Claude Chesnais (1996) points to the contrasting levels of compatibility between work and family in Italy and Sweden in accounting for the ultra-low fertility in the former compared to merely low fertility in the latter. Peter McDonald (1997) makes an analogous argument in terms of the differing degrees of "gender equity" found in the workplace and in the social institutions bearing on the family. Of course the market itself may offer a partial corrective, if demographic conditions lead to heightened competition in the "family-friendliness" of personnel policies. Corporate acceptance of flexible working hours and provision of child care may well be a rational practice. However, such measures would probably not reach a large proportion of the labor force.

Is a pronatalist design of society even possible under modern conditions? Marc Linder (1997) is skeptical. At the end of a dense, insightful commentary on the social and population policy literature, he sets out "desiderata of an intergenerational demographic solidarity." He sees the problem as one of developing a "sustained psychological identification" of individuals with a collectivity that has a past and a future- "a task that is difficult enough in a tabula rasa microcommunity such as a kibbutz, where the generational existential context is palpable, but becomes almost impossibly heroic even in a relatively homogeneous nation" (Linder, p. 313). Let alone, he adds, for a country as "quasireligiously opposed to planning" as the United States (p. 314). 
That is perhaps too defeatist. James Coleman (1993), in his presidential address to the American Sociological Association, took a far more upbeat view of the problem. The societal shift away from what he terms "primordial social organization" centered on the family is held to be irreversible, along with the erosion of the social capital it embodied. However, he argues that the new social system emerging is not foreordained: it is being constructed, and there is scope for ensuring that its institutions are rationally designed. The hope would be for "a future in which social control no longer depends principally on coercion, constraint, and negative sanctions, under the oppressive blanket of closed communities, but instead depends principally on positive incentives and rewards for performance" (p. 14).

One consequence of the loss of social capital just mentioned has been a "vacuum in child rearing." The state increasingly strips that function away from parents - through daycare and schools_-but does not properly replace it: the state's concerns are more with the imparting of skills than with raising good citizens. Coleman proposes a design of incentives to reaffirm parents' rights in their children in a way that maximizes not the child's welfare (which easily becomes parents' welfare) but the child's value to society-a strong interest of the state. The device is to vest a share of the realized increase in that value in the parents or other care givers. A more elaborated model describing a similar institutional innovation, seen as a pronatalist measure as well, was earlier proposed by Paul Demeny (1987). In it, some portion of the social security taxes paid by the children (under a pay-as-you-go system) would be earmarked for their parents. And much the same suggestion is made by Shirley Burggraf (1997).

The particular merits of this kind of proposal (it surely would have difficulties too: Peter Uhlenberg 1997 finds it entirely unfeasible) are less important for my purpose here than its representing a class of intervention that could potentially pass democratic muster. The comparative modesty of such interventions and the test applied to them of public acceptability in a civil society would save 
them from the trenchant criticism advanced by James Scott (1998) of many overweening state efforts in social engineering in recent decades, efforts that have frequently gone seriously awry.

Paul Demeny (1986a: 487) ended his 1986 presidential address to the Population Association of America by posing the "daring questions" that demographers shy away from: "What kind of society would we like to be part of? What kind of arrangements should that society have concerning demographic matters?"- the latter defining "the desirable demographic constitution of contemporary societies." Coleman's 1993 address ended with a very similar challenge to sociologists to engage in normative thinking about the design of society. With such evident problems ahead, there is an urgent task for social scientists in exploring those constitutional issues.

\section{ENRICHING FERTILITY THEORY}

Government, I have argued, is routinely omitted from fertility theory except in a few formulaic categories: manager of family planning programs, legislator on marriage and birth control methods, the fount of "political will," and so on. I have sketched the actual range of plausible governmental influence on fertility, extending across virtually the entire spectrum of fertility determinants and fertility levels. How should fertility theory be expanded to acknowledge these relationships?

A short answer would be that fertility theory should pay more attention to institutional and cultural dynamics, where government actions are generated and where, sporadically and to a limited degree, they have their greatest effect. Thus, beneath the veneer of a poor-country government "adopting" a population policy and setting up a family planning program there may be a real policy process unfolding in which the impetus for collective action on high fertility gains ground. Or, just as likely and just as consequential, there may be no such process: fertility 
instead is left to the benefit-cost calculations of individuals and families-informed, however, by a changing social and economic environment that itself is influenced by government actions. Stripping away that veneer (and with it the hermetic language of latent demand, unmet need, wanted and unwanted births, and program effort) makes the problem of behavioral explanation in fertility not a sui generis exercise for adepts but one with close parallels in other spheres of behavior where economic, social structural, and ideational factors routinely intermingle. It also leaves the high-fertility case far closer to that of low fertility.

There are of course longer answers too. The dimensions of state influence on fertility I have examined define a view of fertility determination in both transitional and post-transitional societies. In that view, the individual perceptions and choices that lead to particular fertility outcomes are conditioned by a broad array of characteristics of the social and economic environment. The information and incentives offered by programmatic interventions in support of anti(or pro-) natalist ends are one of these characteristics. Others where the state is potentially influential are the legal and administrative systems, the opportunity structure of the society, the direction and scale of intergenerational transfers in the public and private economies, and the sense of cultural continuity and intergenerational solidarity that people feel. In the course of development, these characteristics are transformed, generating - or modulating - the familiar transition from high to low fertility. There is no unique path of development, so no single pattern of fertility transition. Moreover, when low fertility is reached, these conditioning factors do not then cease to operate: fertility is still responsive to them.

This is a "demand" approach to fertility, but not an individualistic approach. All it assumes at the individual level is that the components of fertility behavior are not more or less "rational" than most other behaviors. (Biological factors might be a somewhat more significant ingredient, as some would argue.) Fertility is consequential for societies, and societies have developed elaborate 
ways of influencing it. With exogenous mortality declines and the institutional changes wrought by development, however, those social influences on fertility may erode or may have effects that in the new circumstances detract from societal welfare. Fertility is typically too high during development, too low after it: a problem for public policy. A necessary first step in searching for possible remedies is to identify where government already bears on fertility, intentionally or not. Commonly, in high-fertility situations, explicit birth control programs are seen, if not as the only means for government intervention, at least as the most direct and probably most efficacious means. But that may not be so, as the discussion above would tend to suggest. In low-fertility situations, governments may think they have no effective recourse to sustain near-replacement fertility, and that too I questioned.

In modeling we can counterfactually alter government policy settings at will. That is hardly a realistic exercise. Indeed, if that could be readily done in practice, we might suspect that the policy at issue had little bite. In many respects the state can be regarded as a largely endogenous element in understanding fertility-high, declining, and low. Moreover, as I noted at the outset, government is not a simple entity. The committees, agencies, and offices it comprises each have political or bureaucratic interests in survival and wellbeing in addition to their policy or program goals - the latter in part reflecting a response to (or anticipation of) changing community wishes. The context within which fertility is determined is in turn modified by these interests, policies, and programs. Thus the management or oversight of (for example) family law and related tax issues, public-sector intergenerational transfers, labor market policy, and the organization and financing of health and education-all matters that are potentially highly relevant to fertility outcomes-are spread over the bureaucratic map. Intricate as it may be, fertility theory will remain critical in designing societal responses to the problems of population growth and decline. 


\section{References}

Anderson, Benedict. 1991. Imagined Communities: Reflections on the Origins and Spread of Nationalism. London: Verso.

Ben-Porath, Yoram. 1974. "The micro-economics of fertility," International Social Science Journal 26: 302-314.

Blake, Judith. 1972a. "Coercive pronatalism and American population policy," in Commission on Population Growth and the American Future, Aspects of Population Growth Policy. Washington, DC. (Research Reports, volume 6.)

Blake, Judith. 1972b. "Fertility control and the problem of voluntarism," in Scientists and World Affairs: Proceedings of the 22nd Pugwash Conference. Reprinted in Population and Development Review 20 (1994): 167-177.

Blake, Judith. 1985. "Number of siblings and educational mobility," American Sociological Review 50: 84-94.

Burggraf, Shirley P. 1997. The Feminine Economy and Economic Man: Revising the Role of Family in the Post-Industrial Age. Reading, MA: AddisonWesley.

Canovan, Margaret. 1996. Nationhood and Political Theory. Cheltenham, U.K.: Edward Elgar.

Chand, Gyan. 1954. Some Aspects of the Population Problem of India. Bihar: Patna University.

Chenery, Hollis and Moshe Syrquin. 1975. Patterns of Development, 1950-1970. New York: Oxford University Press.

Cherlin, Andrew J. (ed.) 1988. The Changing American Family and Public Policy. Washington, DC: Urban Institute Press.

Chesnais, Jean-Claude. 1996. "Fertility, family, and social policy in contemporary Western Europe," Population and Development Review 22: 729-739. 
Coleman, James S. 1993. "The rational reconstruction of society," American Sociological Review 58: 1-15.

Davis, Kingsley. 1937. "Reproductive institutions and the pressure for population," Sociological Review. Reprinted in Population and Development Review 23 (1997): 611-624.

Demeny, Paul. 1979. "On the end of the population explosion," Population and Development Review 5: 141-162.

Demeny, Paul. 1986a. "Population and the invisible hand," Demography 23: 473487.

Demeny, Paul. 1986b. "Pronatalist policies in low-fertility countries: patterns, performance, and prospects," in Kingsley Davis et al., eds., Below-Replacement Fertility in Industrial Societies: Causes, Consequences, Policies. New York: Cambridge University Press.

Demeny, Paul. 1987. "Re-linking fertility behavior and economic security in old age: A pronatalist reform," Population and Development Review 13: 128132.

Demeny, Paul. 1997. "Policy interventions in response to below-replacement fertility," paper prepared for the United Nations Expert Group Meeting on Below-Replacement Fertility, New York, November.

Espenshade, Thomas J. 1984. Investing in Children: New Estimates of Parental Expenditures. Washington, DC: Urban Institute Press.

Esping-Andersen, Gøsta. 1996. Welfare States in Transition: National Adaptations in Global Economies. London: Sage Publications.

Fargues, Philippe. 1997. "State policies and the birth rate in Egypt: From socialism to liberalism," Population and Development Review 23: 115-138.

Furstenberg, Frank F., Jr. 1995. "Family change and the welfare of children: What do we know and what can we do about it?" in Karen Oppenheim Mason 
and An-Magritt Jensen, eds., Gender and Family Change in Industrialized Countries. Oxford: Clarendon Press.

Geertz, Clifford. 1963. "The integrative revolution: Primordial sentiments and civil politics in the new states," in Clifford Geertz, ed., Old Societies and New States: The Quest for Modernity in Asia and Africa. New York: Free Press.

Goodkind, Daniel M. 1995. "Vietnam's one-or-two-child policy in action,” Рориlation and Development Review 21: 85-111.

Greenhalgh, Susan. 1988. "Fertility as mobility: Sinic transitions," Population and Development Review 14: 629-674.

Greenhalgh, Susan. 1990. "Land reform and family entrepreneurship in East Asia," in Geoffrey McNicoll and Mead Cain, eds., Rural Development and Population: Institutions and Policy. New York: Oxford University Press.

Jones, E.L. 1988. Growth Recurring: Economic Change in World History. Oxford: Oxford University Press.

Kaplan, Hillard. 1994. "Evolutionary and wealth flows theories of fertility: Empirical tests and new models," Population and Development Review 20: 753-791.

Kaplan, Robert D. 1996. The Ends of the Earth: A Journey at the Dawn of the 21 st Century. New York: Random House.

Lee, Ronald D. 1994. "The formal demography of population aging, transfers, and the economic life cycle," in Linda Martin and Samuel Preston, eds., The Demography of Aging. Washington, DC: National Academy Press.

Lee, Ronald D. and Timothy Miller. 1997. "The life-time fiscal impacts of immigrants and their descendants," draft of Chapter 7 of The New Americans, a report of the National Research Council Panel on Economic and Demographic Consequences of Immigration (National Academy Press, 1997). 
Lesthaeghe, Ron. 1983. "A century of demographic and cultural change in Western Europe: An exploration of underlying dimensions," Population and Development Review 9: 411-435.

Lesthaeghe, Ron. 1995. "The second demographic transition in Western countries: An interpretation," in Karen Oppenheim Mason and An-Magritt Jensen, eds., Gender and Family Change in Industrialized Countries. Oxford: Clarendon Press.

Linder, Marc. 1997. The Dilemmas of Laissez-Faire Population Policy in Capitalist Societies: When the Invisible Hand Controls Reproduction. Westport, CT: Greenwood Press.

Malthus, T. R. 1820. Principles of Political Economy. Reprinted in The Works of Thomas Robert Malthus, ed. E. A. Wrigley and David Souden. London: Pickering, 1986, Vol. 5.

McDonald, Peter. 1997. "Gender equity, social institutions and the future of fertility," Working Papers in Demography No. 69, Research School of Social Sciences, Australian National University, Canberra.

McIntosh, C. Alison. 1986. "Recent pronatalist policies in Western Europe," in Kingsley Davis et al., eds., Below-Replacement Fertility in Industrial Societies: Causes, Consequences, Policies. New York: Cambridge University Press.

McNeill, William H. 1984. "Human migration in historical perspective," Рориlation and Development Review 10: 1-18.

McNicoll, Geoffrey. 1997. "The governance of fertility transition: Reflections on the Asian experience," in Gavin W. Jones et al., eds., The Continuing Demographic Transition. Oxford: Clarendon Press.

Migdal, Joel S. 1988. Strong Societies and Weak States. Princeton: Princeton University Press. 
Potts, Malcolm. 1997. "Sex and the birth rate: Human biology, demographic change, and access to fertility-regulation methods," Population and Development Review 23: 1-39.

Preston, Samuel H. 1984. "Children and the elderly: Divergent paths for America's dependents," Demography 21: 435-457.

Pritchett, Lant H. 1994. "Desired fertility and the impact of population policies," Population and Development Review 20: 1-55.

Putnam, Robert D. 1993. Making Democracy Work: Civic Traditions in Modern Italy. Princeton: Princeton University Press.

Schultz, T. Paul. 1994. "Human capital, family planning, and their effects on population growth," American Economic Review 84: 255-260.

Scott, James C. 1985. Weapons of the Weak: Everyday Forms of Peasant Resistance. New Haven: Yale University Press.

Scott, James C. 1998. Seeing Like a State: How Certain Schemes to Improve the Human Condition Have Failed. New Haven: Yale University Press.

Sowell, Thomas. 1983. The Economics and Politics of Race: An International Perspective. New York: Morrow.

Taussig, F. W. 1911. Principles of Economics. New York: Macmillan.

Uhlenberg, Peter. 1997. Review of Shirley P. Burggraf, The Feminine Economy and Economic Man. Population and Development Review 23: 662-663.

van de Kaa, Dirk J. 1996. "Anchored narratives: The story and findings of half a century of research into the determinants of fertility," Population Studies 50: 389-432.

Veil, Simone. 1978. "Human rights, ideologies, and population policies," Рориlation and Development Review 4: 313-321. 
Warwick, Donald J. 1982. Bitter Pills: Population Policies and Their Implementation in Eight Developing Countries. New York: Cambridge University Press.

Willis, Robert J. 1994. "Economic analysis of fertility: Micro foundations and aggregate implications," in Kerstin Lindahl-Kiessling and Hans Landberg, eds., Population, Economic Development, and the Environment. Oxford: Clarendon Press.

Willis, Robert J. 1998. "Economic transformation and fertility," paper presented at the Conference on Global Fertility Transition, Bellagio, Italy, May.

Yergin, Daniel and Joseph Stanislaw. 1998. The Commanding Heights: The Battle Between Government and the Marketplace That Is Remaking the Modern World. New York: Simon and Schuster.

Zhang Weiguo. 1998. "Economic reforms and fertility behaviour: A study of a northern Chinese village," Ph.D. dissertation, Institute of Social Studies, The Hague. 


\title{
POLICY RESEARCH DIVISION WORKING PAPERS
}

\author{
Recent Back Issues
}

* 83 Sajeda Amin, Ian Diamond, and Fiona Steele, "Contraception and religious practice in Bangladesh."

84 John B. Casterline, Aurora E. Perez, and Ann E. Biddlecom, "Factors underlying unmet need for family planning in the Philippines."

85 Geoffrey McNicoll, "Governance of fertility transition: Regularity and duress."

*86 John Bongaarts, "Population pressure and the food supply system in the developing world."

87 Sajeda Amin, "Family structure and change in rural Bangladesh."
*88 John Bongaarts and Susan Cotts Watkins, "Social interactions and contemporary fertility transitions."

*89 Cynthia B. Lloyd and Mark R. Montgomery, "The consequences of unintended fertility for investments in children: Conceptual and methodological issues."

* 90 Zeba Sathar and Sonalde Desai, "Work patterns in rural Pakistan: Intersections between gender, family, and class."

*91 Mark R. Montgomery, "Learning and lags in mortality perceptions."

92 Ann E. Biddlecom, John B. Casterline, and Aurora E. Perez, "Men's and women's views of contraception."
93 James F. Phillips, Fred N. Binka, Martin Adjuik, Alex Nazzar, and Kubaze Frank Adazu, "The determinants of contraceptive innovation: A case-control study of family planning acceptance in a traditional African society."

94 John Bongaarts and Sajeda Amin, "Prospects for fertility decline and implications for population growth in South Asia."
95 Barbara S. Mensch and Cynthia B. Lloyd, "Gender differences in the schooling experiences of adolescents in low-income countries: The case of Kenya."

96 Martin Brockerhoff and Ellen Brennan, "The poverty of cities in the developing world."

* No longer available 
97Carol E. Kaufman, "Reproductive control in South Africa."

98 John Bongaarts, "Trends in unwanted childbearing in the developing world."

99 Mary Arends-Kuenning, "How do family planning workers' visits affect women's contraceptive behavior in Bangladesh?"

100 Mark R. Montgomery and Cynthia B. Lloyd, "Excess fertility, unintended births, and children's schooling."

101 Mary Arends-Kuenning, "The equity and efficiency of doorstep delivery of contraceptives in Bangladesh."
102 Sajeda Amin, Ian Diamond, Ruchira T. Naved, and Margaret Newby, "Transition to adulthood of female factory workers: Some evidence from Bangladesh."

*103 Margaret E. Greene and Ann E. Biddlecom, "Absent and problematic men: Demographic accounts of male reproductive roles."

104 Michael P. Todaro, "Urbanization, unemployment, and migration in Africa: Theory and policy."

105 Geoffrey McNicoll, "Population and poverty: A review and restatement."

\section{8}

106 Sajeda Amin and Gilda Sedgh, "Incentive schemes for school attendance in rural Bangladesh."

107 Martin Brockerhoff and Paul Hewett, "Ethnicity and child mortality in subSaharan Africa."

108 Ann E. Biddlecom and Bolaji M. Fapohunda, "Covert contraceptive use: Prevalence, motivations, and consequences."

109 John Bongaarts and Griffith Feeney, "On the quantum and tempo of fertility."

110 Barbara S. Mensch, Daniel Bagah, Wesley H. Clark, and Fred Binka, "The changing social environment for adolescents in the Kassena-Nankana District of northern Ghana: Implications for reproductive behavior."

111 Martin Brockerhoff and Ann Biddlecom, "Migration, sexual behavior, and HIV diffusion in Kenya."

112 Zeba A. Sathar and John B. Casterline, "The onset of fertility transition in Pakistan."

113 Geoffrey McNicoll, "Government and fertility in transitional and post-transitional societies." 